IFAS Extension

\title{
Florida Foliage House Plant Care: Spathiphyllum ${ }^{1}$
}

\author{
R. J. Henny and J. Chen ${ }^{2}$
}

\section{Introduction}

Most Spathiphyllum are seen in flower when at market (Figure 1). The attractive white blooms, called spathes, are long lasting. With proper plant care, Spathiphyllum may produce blooms year after year. Spathiphyllum is a very attractive house plant even when not in bloom and adapts well to home and patio environments.

Common names: Spathiphyllum, peace lily

Scientific name: Spathiphyllum spp.

Plant family: Araceae (the aroid family)

\section{Indoor/Home/Office Cultivation Information}

Light requirement: Bright, indirect light. No direct sun.

Soil preference: Rich, organic peat or bark-based, bagged potting soil.

Water requirement: Keep moist, but do not allow Spathiphyllum to sit in water.

Drought tolerant: Slightly tolerant.

Fertilizer requirements: Apply a low dose of liquid fertilizer according to manufacturer instructions three times per year.

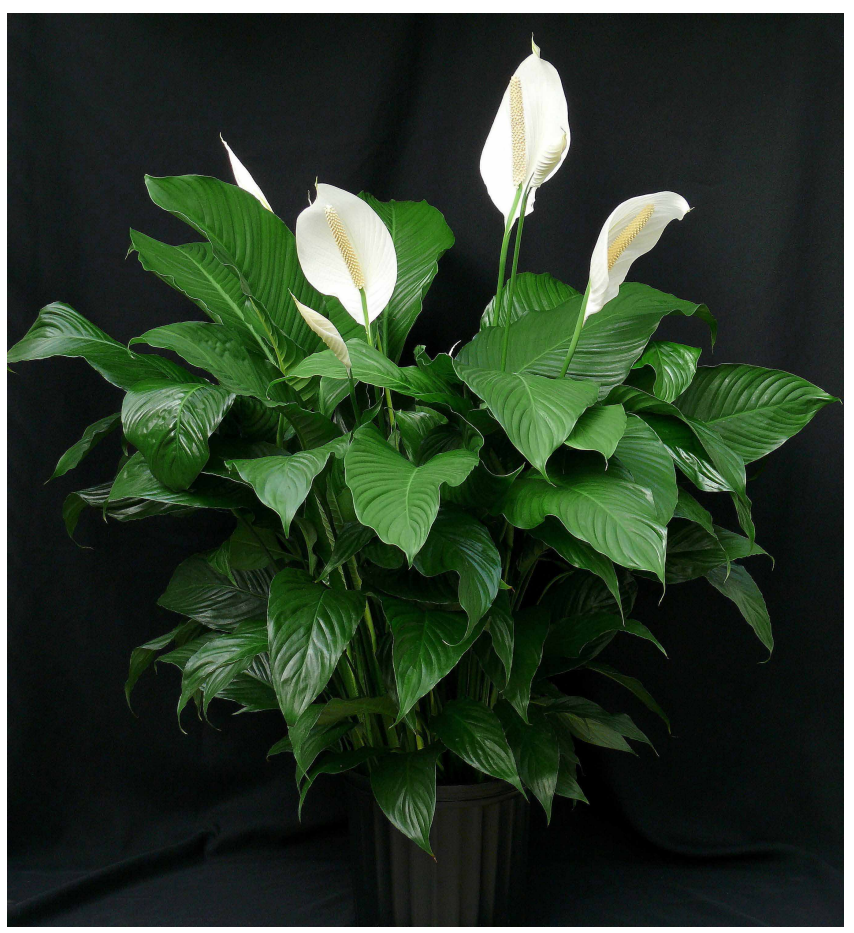

Figure 1. Spathiphyllum 'Sweet Pablo' in a 2-gallon container. Credits: Gary Hennen

Temperature preference: Warm, tropical, $75^{\circ} \mathrm{F}-85^{\circ} \mathrm{F}$.

Chill tolerant $\left(55^{\circ} \mathrm{F}-35^{\circ} \mathrm{F}\right)$ : Moderately tolerant; some cultivars can be injured at $35^{\circ} \mathrm{F}$; active growth is reduced at or below $50^{\circ} \mathrm{F}$.

Freeze tolerant (below $\left.32^{\circ} \mathrm{F}\right)$ : No.

Salt tolerant: No.

1. This document is ENH1216, one of a series of the Environmental Horticulture Department, UF/IFAS Extension. Original publication date June 2013. Visit the EDIS website at http://edis.ifas.ufl.edu.

2. R. J. Henny and J. Chen, professors, Department of Environmental Horticulture, UF/IFAS Mid-Florida Research and Education Center, Apopka, FL 32703.

The Institute of Food and Agricultural Sciences (IFAS) is an Equal Opportunity Institution authorized to provide research, educational information and other services only to individuals and institutions that function with non-discrimination with respect to race, creed, color, religion, age, disability, sex, sexual orientation, marital status, national origin, political opinions or affiliations. U.S. Department of Agriculture, Cooperative Extension Service, University of Florida, IFAS, Florida A\&M University Cooperative Extension Program, and Boards of County Commissioners Cooperating. Nick T. Place, Dean 
Pests: Mealybug, scale - Take a sample to your local UF/ IFAS Extension agent to confirm identification and receive treatment instructions.

\section{Outdoor Cultivation Information}

Outdoor year-round planting: Okay for USDA Hardiness Zones 10B-12.

Soil preference: Well drained, amended with organic matter.

Light requirement: No direct sun.

Water requirement: Irrigate regularly; maintain moisture but provide drainage.

Drought tolerant: Slightly tolerant.

Fertilizer requirements: Apply a well-balanced, slowrelease, pelletized fertilizer according to manufacturer recommendations during the warm growing season.

Salt tolerant: No.

Temperature preference: Warm, tropical, $75^{\circ} \mathrm{F}-85^{\circ} \mathrm{F}$.

Chill tolerant $\left(55^{\circ} \mathrm{F}-35^{\circ} \mathrm{F}\right)$ : Moderately tolerant; some cultivars can be injured at $35^{\circ} \mathrm{F}$; active growth is reduced at or below $50^{\circ} \mathrm{F}$.

Freeze tolerant (below $32^{\circ} \mathrm{F}$ ): No.

Pests: Mites, scale - Take a sample to your local UF/IFAS Extension agent to confirm identification and receive treatment instructions.

Notes: Spathiphyllum varieties are numerous and range in size from small plants in 4-inch pots to specimen sizes in 7-gallon pots or larger (Figure 2).

Availability: Spathiphyllum is readily available year-round at retail outlets, florists, garden centers, and nurseries.

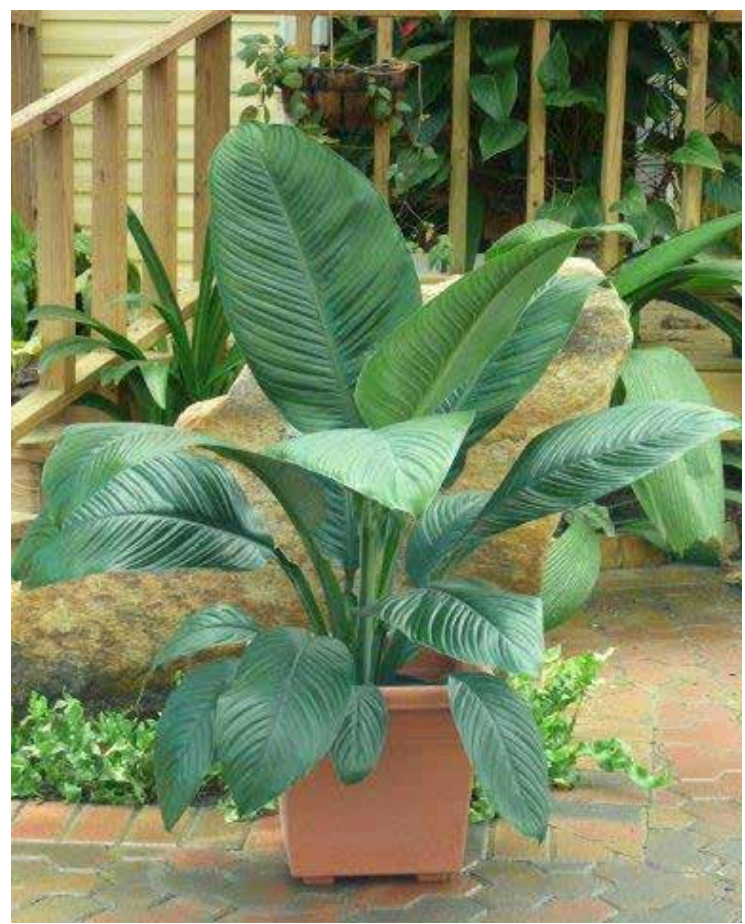

Figure 2. Spathiphyllum 'Sensation' in a 7-gallon planter. Credits: Jim Georgisus

\section{Additional Resources}

Watkins, J. V., and T. J. Sheehan. 1975. Florida Landscape Plants, Native and Exotic. Gainesville: University Press of Florida. 